\title{
Phase and facet-engineering of transition alumina leads to (hydro)thermally stable alumina-supported metal catalysts
}

\author{
Authors: Konstantin Khivantsev ${ }^{1 *} \dagger$, Ja-Hun Kwak ${ }^{2 *} \dagger$, Nicholas R. Jaegers ${ }^{1}$, Yong Wang, ${ }^{1,3^{*}}$ \\ Janos Szanyi ${ }^{*}$ and Libor Kovarik ${ }^{1 *} \dagger$
}

\author{
Affiliations: \\ ${ }^{1}$ Institute for Integrated Catalysis, Pacific Northwest National Laboratory, Richland, WA, USA \\ ${ }^{2}$ Ulsan National Institute of Science and Technology (UNIST), Ulsan, South Korea \\ ${ }^{3}$ The Gene \& Linda Voiland School of Chemical Engineering and Bioengineering, Washington \\ State University, Pullman, WA, USA \\ * Correspondence to: LK, JHK, JSz, KK \\ $\uparrow$ denotes equal contribution
}

\begin{abstract}
Inherent thermal instability of gamma-alumina above $800-900^{\circ} \mathrm{C}$ leads to deactivation of noble metal-supported alumina catalysts used in automotive applications. This is typically solved by adding toxic (barium) and/or rare-earth (lanthanum, cerium) elements. We show that facet-dependent engineering of transition-alumina leads to (hydro)thermally stable supported metal catalysts in the absence of toxic and rare-earth additives. Since pure high-surface area thetaalumina can be prepared at 1,050-1,100 ${ }^{\circ} \mathrm{C}$ directly from gamma-alumina (or boehmite), and because of its stable major (100) facet with very low surface energy of $597 \mathrm{~mJ} / \mathrm{m}^{2}$, we succeeded in preparing $\sim 0.07 \mathrm{wt} \% \mathrm{Rh}$ and $\sim 3 \mathrm{wt} \% \mathrm{Pd}$ catalysts active in NO reduction and hydrocarbon oxidation that survive hydrothermal aging up to $1,100{ }^{\circ} \mathrm{C}$ with little-to-no deactivation.
\end{abstract}

$\gamma$-alumina first caught the attention of the catalysis and materials communities in 1902 when Vladimir Ipatieff discovered it to be a robust and stable alcohol dehydration material, followed by its triumphant, continuous use in petrochemical organics production [1]. Since then, it has remained one of the largest scale heterogeneous materials produced industrially. It features high surface area and attractive mechanical properties [2-8]. For this reason, $\gamma$-alumina found an application as a support for metals [1-8] (metal and metal oxide nanoparticles, single ions) for catalytic removal of nuisance pollutants in vehicles: the majority of alumina produced nowadays is used specifically for this very purpose. Catalysts in vehicles are exposed to extremely harsh thermal conditions in the presence of water vapor. For example, in gasoline engines the NO abatement $\mathrm{Rh}$-containing catalysts encounter temperatures up to $1,000{ }^{\circ} \mathrm{C}$ [9]. In diesel engines, hydrocarbon oxidation catalysts, temperatures in excess $900{ }^{\circ} \mathrm{C}$ may be encountered during diesel 
particular filter regeneration [10]. Thermal treatment of gamma-alumina above $800{ }^{\circ} \mathrm{C}$ leads to continuous phase transformation to delta and theta-phases [9-10]. Simultaneously, this phase change leads to the mobility of the surface and metal-alumina interface, leading to coverage of metal-containing phases with alumina, dissolution of metals in the bulk of alumina (for rhodium) and growth of metal/metal oxide nanoparticles [9-20]. Due to this process, the catalytic activity of precious metal containing alumina materials is greatly diminished. The industry deals with this degradation process by putting textural promoters on the surface alumina, which are toxic and expensive: such as barium and rare earths (lanthanum, ceria, etc). Currently, there is a strong need to develop hydrothermally stable alumina catalysts without addition of toxic and rare-earth elements. To date, it has not been realized.

Our efforts to understand transition aluminas culminated in a number of fundamental insights regarding the structure and surface of these unique materials [8-10, 14-17]: more specifically, it was shown that the $\delta$-structure is an intergrowth structure of multiple variants of $\delta_{1,2,3,4}-\mathrm{Al}_{2} \mathrm{O}_{3}$ that can intergrow in two different crystallographic directions [14-17]. $\theta-\mathrm{Al}_{2} \mathrm{O}_{3}$ was found to be a structure that can be interpreted as a structure consistent with $\beta-\mathrm{Ga}_{2} \mathrm{O}_{3}$ phase but containing a high density of $\delta-\mathrm{Al}_{2} \mathrm{O}_{3}$-like inclusions that significantly modify the bonding environment. Because we now understand the structure of transition aluminas, we can begin to understand why they evolve continuously from gamma-alumina: the energies of different delta and theta phases are quite similar (Fig. S1), leading to their continuous evolution upon heating to $1,000{ }^{\circ} \mathrm{C}$. This evolution may only be close to complete after prolonged heating at $1,050{ }^{\circ} \mathrm{C}[9,10]$.

We find that typical high-surface commercial gamma-aluminas such as SBA-200 (containing small platelet nanocrystals and nanocrystals of poorly defined shapes [8], surface area $\sim 180 \mathrm{~m}^{2} / \mathrm{g}$ ) transforms into a mixture of delta/theta above $900^{\circ} \mathrm{C}$ (Fig. S2) and starts forming low-surface-area alpha-alumina already at $1,050-1,100^{\circ} \mathrm{C} .[9,10,18]$. On the other hand, Rhombus-platelet gammaalumina (surface area $\sim 70 \mathrm{~m}^{2} / \mathrm{g}$ ) has larger crystal size than SBA-200 [and it exposes macroscopically defined (110) and (111) facets mostly, [8]]: it continually transforms into a mixture of delta/theta phases (Fig. S3) and this transformation essentially ceases after 48 hours of $1,050^{\circ} \mathrm{C}$ heating [10], meaning no phase transformation occurs at an appreciable rate after that. Here, we hypothesized that the transition alumina support with high surface area and high proportion of a surface facet with the lowest possible energy would be able to withstand harsh hydrothermal treatment conditions without undergoing deteriorating phase- and surface 
transformations. Specifically, we focus on the use of transition Alumina in the form of theta-phase, (which is the most stable polymorph of transition Aluminas [9,10]), and more importantly on optimizing the morphology for high temperature stability. Transition aluminas are generally made through a topotactic phase transformation from decomposition of Boehmite. In this process, external surfaces of transition alumna are inherited from the initial shape of Boehmite. Since the initial shape often does not represent the most stable surfaces, this would naturally lead to inherent instability and driving force for morphological transformations.

Herein, we take advantage of the fact that different surface facets have different surface stability (i.e., surface energy). Among transition alumina polymorphs, the theta-transition alumina polymorph is the one that has the lowest energies of surface facets $[9,10,20]$ (excluding the alphaphase whose surface area drops precipitously). Among possible facets, we calculated the surface energy of the (100) facets of theta-alumina based on our refined structure (Fig. 1) to $597 \mathrm{~mJ} / \mathrm{m}^{2}$. This is lower than DFT calculated values for other theta-alumina facets [20]. This very low value suggests that if we succeed in preparing theta-alumina with pre-dominantly (100) facets we have a chance to prepare (hydro)thermally robust catalysts supported on this type of alumina.
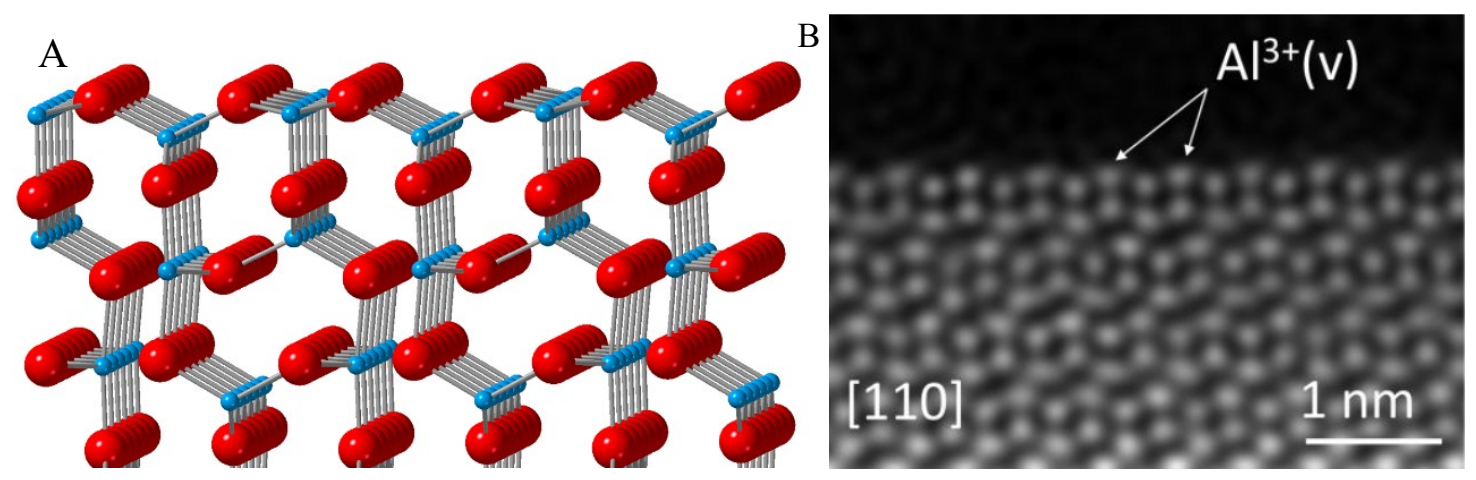

Fig. 1. A. DFT-optimized (100) facet of theta-alumina. The surface features alternating rows of tetra- and penta-coordinate Al atoms. Red - oxygen; Blue - aluminum. B. Atomic level HAADF-STEM image of theta-alumina in the [110] direction with (100) facet, showing $\mathrm{Al}(\mathrm{V})$ penta-coordinated sites alternating with tetra-Al sites.

We took advantage of modern synthesis methods and prepared rod-like gamma alumina, exposing predominantly (100) surface [8]. Because of low surface energy of (100) facets of theta-alumina, we hypothesized that this sample could be directly converted to theta-phase with major (100) facet [phase transformation between metastable gamma-alumina and delta,theta-phases is a topotactic transformation] $[9,10,18]$. To our delight, heating this sample at $1,050^{\circ} \mathrm{C}$ for a few (4) hours leads 
to complete transformation of this sample into rod-like theta-alumina (Fig. 2A) with no additional phase (surface areas of the rold-like gamma- and theta- alumina sample are identical $\sim 75 \mathrm{~m}^{2} / \mathrm{g}$ consistent with a topotactic transformation) (Fig. 2) [please note that heating this sample to even higher temperature $\left(1,100^{\circ} \mathrm{C}\right)$ for extended time also maintains the theta-alumina rod morphology and phase integrity].
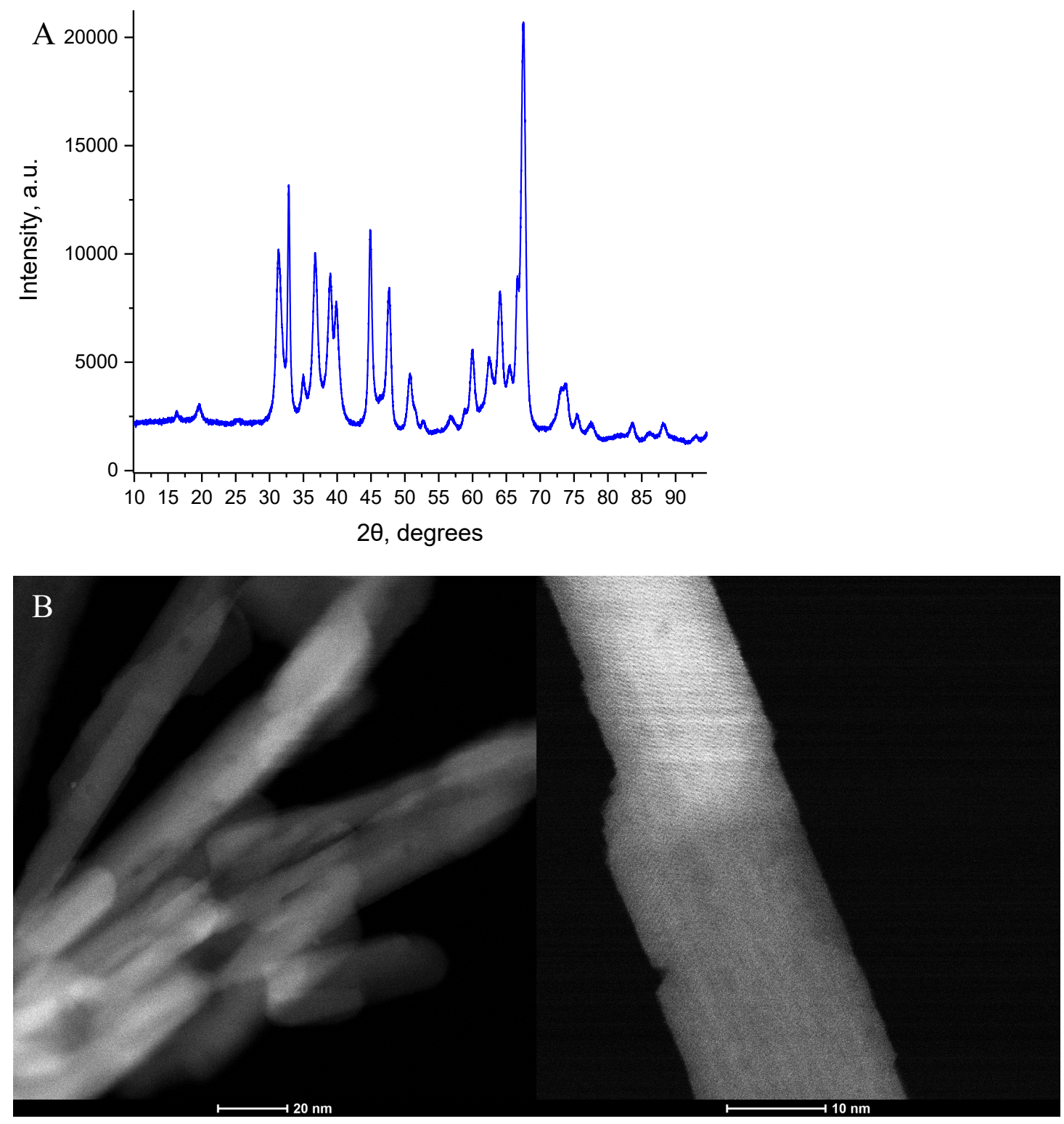

Fig. 2. A. XRD pattern of theta-alumina rods (prepared by heating rod-like gamma-alumina with SA $\sim 75 \mathrm{~m}^{2} / \mathrm{g}$ at $1,050{ }^{\circ} \mathrm{C}$ ) showing pure phase theta-alumina (SA $\sim 75 \mathrm{~m}^{2} / \mathrm{g}$ ); B. Representative HAADF-STEM images of theta-alumina rods.

Because this phase is produced directly at high temperature and does not change at all after it is produced up to $1,100^{\circ} \mathrm{C}$, we hypothesized that due to the stability of this phase with predominant 
(100) facet [that has very low surface energy], the catalytic materials with supported nanoparticles (3wt\% Pd loading, PdO palladium oxide for hydrocarbon oxidation) [22] and single atoms ( $\mathrm{Rh}$, $0.08 \mathrm{wt} \%$, NO reduction by $\mathrm{CO}$ ) [23] could be stable after extremely harsh hydrothermal aging.

Fig. 3 shows activity of $\mathrm{PdO}$ on theta-alumina for methane combustion in the fresh state both under dry and wet conditions going up and down in temperature. The sample shows completely stable methane combustion activity. We then performed extremely harsh hydrothermal aging on this sample continuously in the presence of $10 \% \mathrm{H}_{2} \mathrm{O}$ /Air flow at each temperature for 16 hours $(800$, 900 and $1,000{ }^{\circ} \mathrm{C}$ aged) (Fig. 3).

A
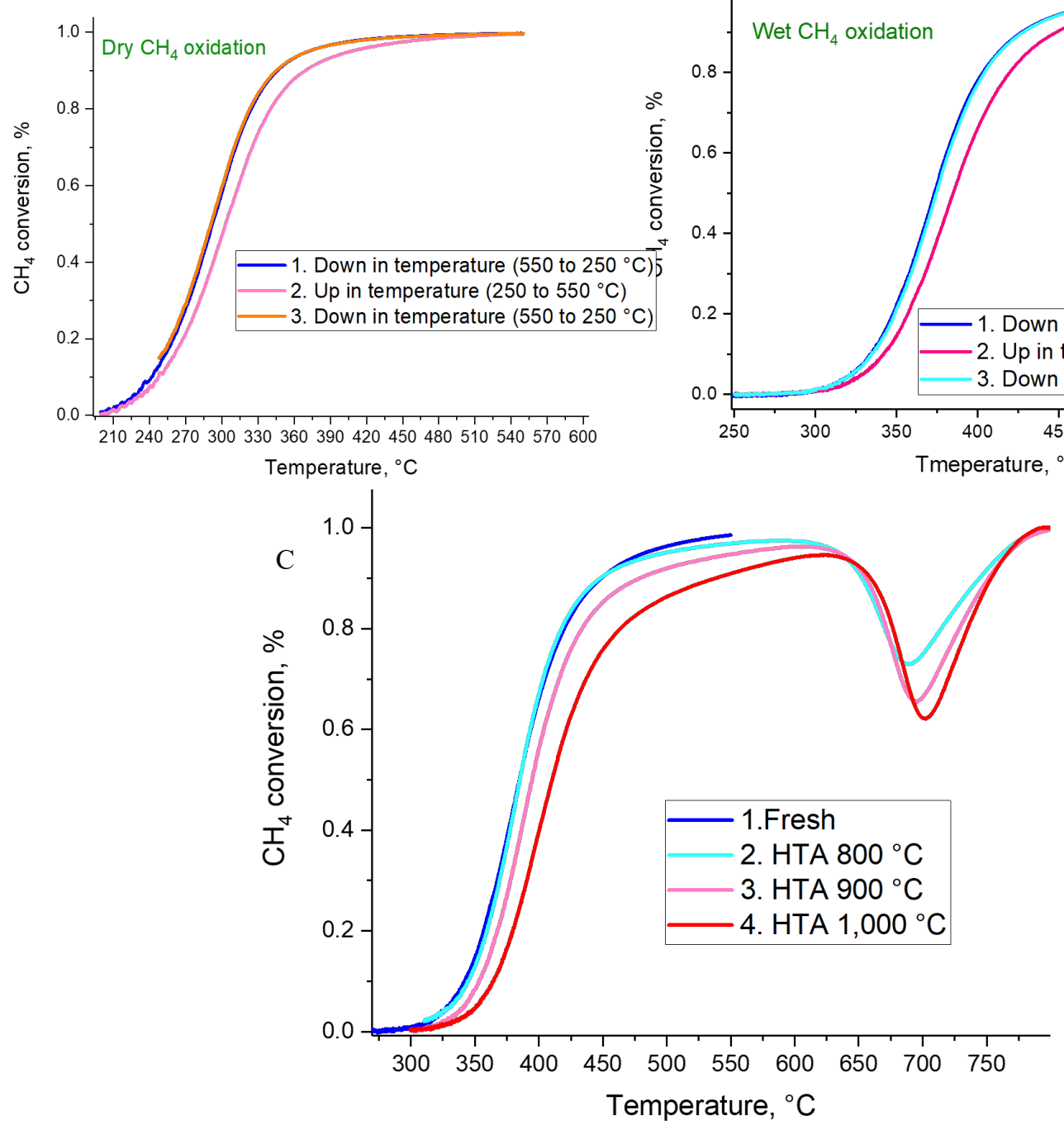

B

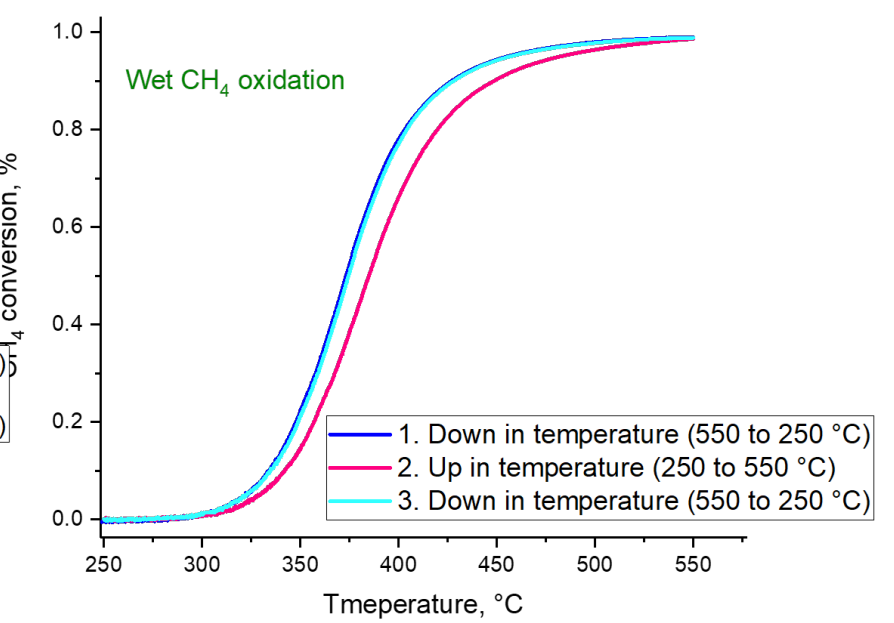

Fig. 3. Activity of fresh $3 \mathrm{wt} \% \mathrm{Pd} /$ theta-alumina sample in methane oxidation: $\mathrm{A}$. In the absence of moisture. $\mathrm{CH}_{4} \sim 850 \mathrm{ppm}, \mathrm{O}_{2}$ $\sim 10 \%$, balance nitrogen. GHSV $\sim 300 \mathrm{~L} / \mathrm{g} * \mathrm{hr}$. Temperature up/down ramp $2{ }^{\circ} \mathrm{C} / \mathrm{min}$. B. In the presence of $\sim 3 \% \mathrm{H}_{2} \mathrm{O}, \mathrm{CH}_{4} \sim 850$ 
ppm, $\mathrm{O}_{2} \sim 10 \%$, balance nitrogen. GHSV $\sim 300 \mathrm{~L} / \mathrm{g} * \mathrm{hr}$. Temperature up/down ramp $2{ }^{\circ} \mathrm{C} / \mathrm{min}$. C. Comparison of activity of $3 \mathrm{wt} \%$ $\mathrm{Pd}$ /theta-alumina in methane combustion (in the presence of moisture) before and after hydrothermal aging. After collecting each methane oxidation curve, the sample was subsequently aged at the desired temperature for 16 hours: then the methane conversion curve was collected while going down in temperature. The sample, thus, was aged 3 times and performance was collected 4 times (before aging, and after each hydrothermal aging cycle). $\sim 3 \% \mathrm{H}_{2} \mathrm{O}, \mathrm{CH}_{4} \sim 850 \mathrm{ppm}, \mathrm{O}_{2} \sim 10 \%$, balance nitrogen. GHSV 300 $\mathrm{L} / \mathrm{g} * \mathrm{hr}$. Temperature cooling rate was $2{ }^{\circ} \mathrm{C} / \mathrm{min}$.

Remarkably, the sample survives with little deterioration whereas typical Pd sample on SBA-200 gamma-alumina is considerably deactivated after $950^{\circ} \mathrm{C}$ aging (Fig. S4). HAADF-STEM images (Fig. 4) of the sample after many hydrothermal aging cycles show that theta-alumina rods in 3 $\mathrm{wt} \% \mathrm{Pd} /$ theta-rods sample do not change and relatively large well-faceted $\mathrm{PdO}$ nanoparticles (that are needed for high activity due to (110) facets on PdO surface [22]) are present.
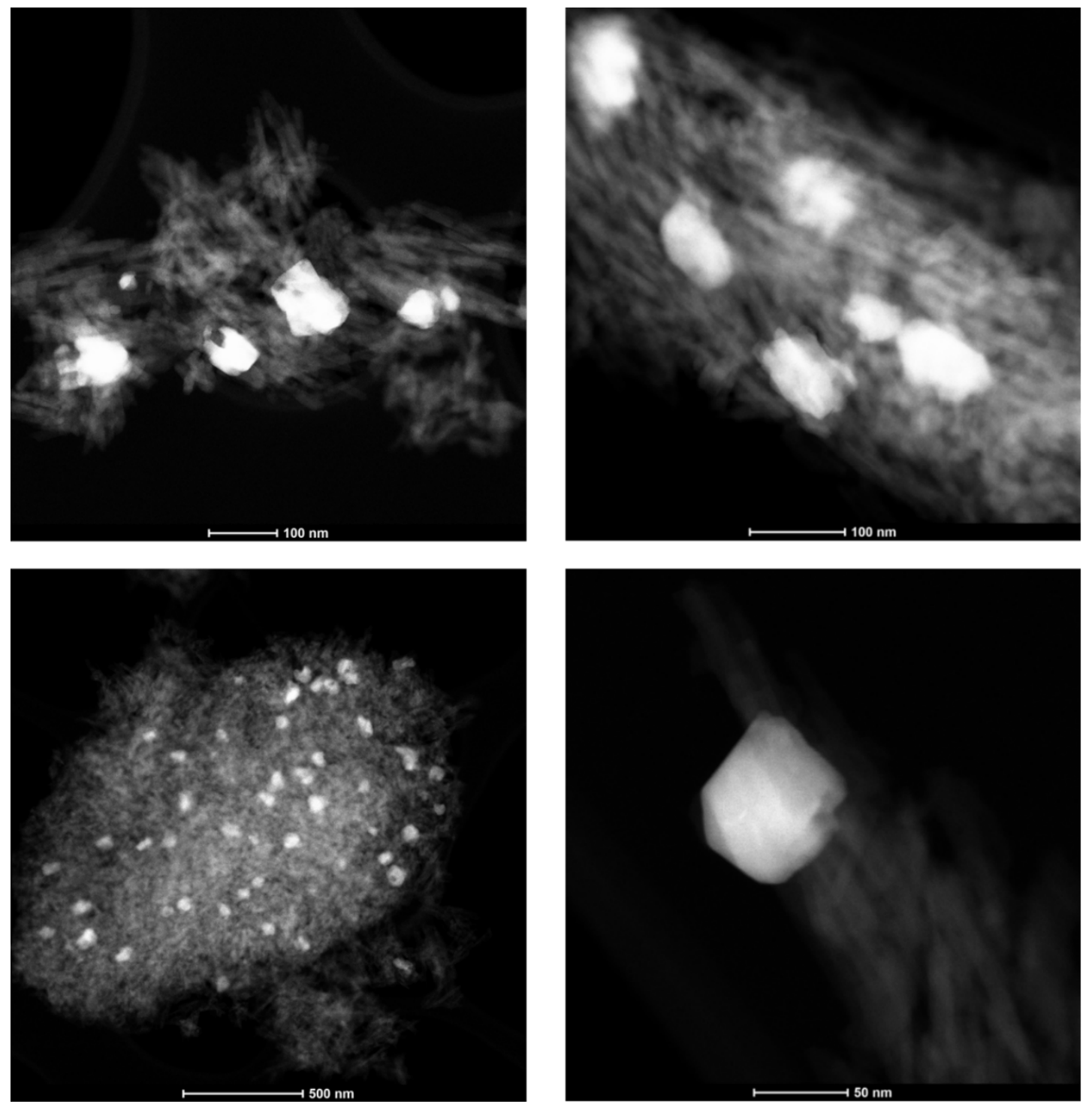
Fig. 4. HAADF-STEM images of the $3 \mathrm{wt} \% \mathrm{Pd} /$ theta-alumina rods sample (hydrothermally aged 3 times at 800,900 and $1,000{ }^{\circ} \mathrm{C}$ ) after methane combustion.

Fig. 5 shows the activity of single-atom Rh theta-alumina sample with low $(0.07 \mathrm{wt} \%)$ loading of $\mathrm{Rh}$ in NO reduction. The sample is active and stable, consistent with previous finding of catalytic activity of isolated $\mathrm{Rh}(\mathrm{I})$ ions for $\mathrm{NO}$ reduction by $\mathrm{CO}[23]$. Hydrothermal aging at $1,000{ }^{\circ} \mathrm{C}$ does not lead to any significant changes in activity unlike typical $\mathrm{Rh} /$ alumina samples (for which $\mathrm{Rh}$ is known to dissolve inside alumina during alumina phase-change), thus alleviating the previous problems for Rh-alumina supported samples that suffer high deactivation (Fig. S5) after hydrothermal aging. Fig. 6 shows that mostly single Rh atoms are present on the sample after HTA treatment, with very few sub-nanometer sized Rh nanoparticles that could be found, consistent with preserved activity of this sample.
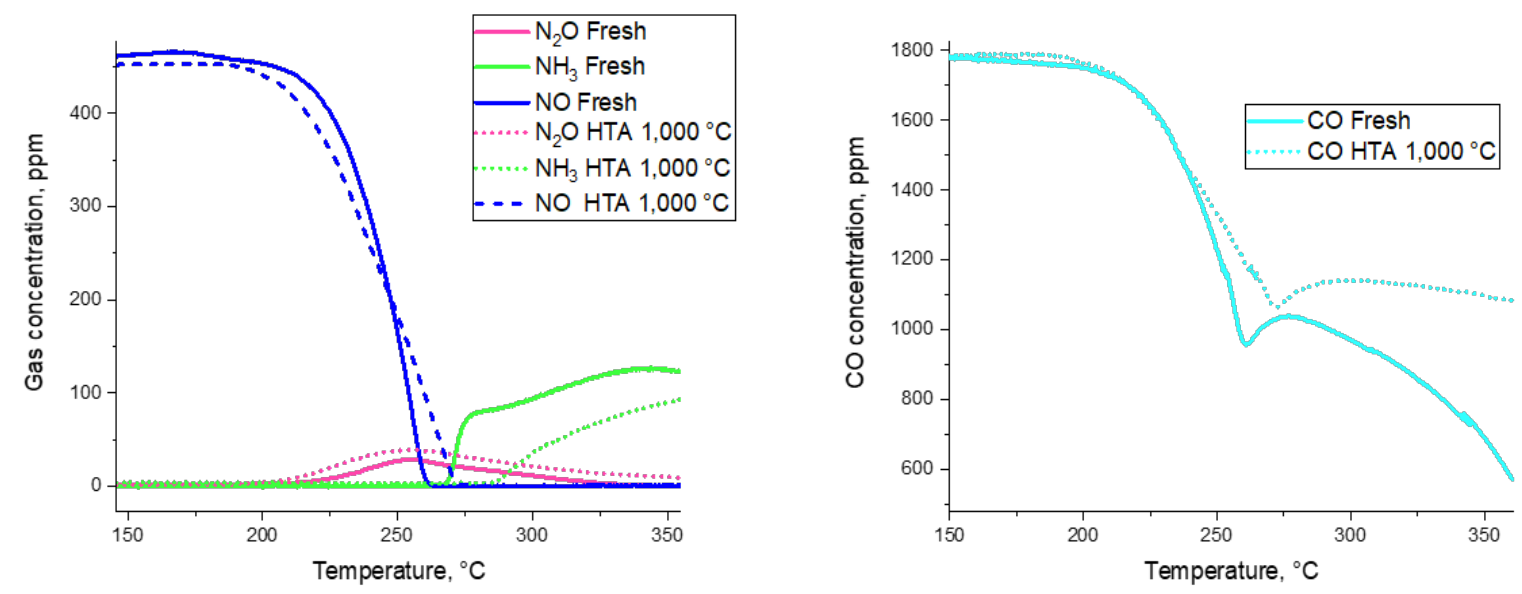

Fig. 5. NO reduction activity of fresh and $1,000{ }^{\circ} \mathrm{C}$ HTA aged $0.07 \mathrm{wt} \% \mathrm{Rh} /$ theta-alumina rods sample. $120 \mathrm{mg}$ catalyst. $450 \mathrm{ppm}$ $\mathrm{NO}, 1,750 \mathrm{ppm} \mathrm{CO}, \sim 3 \% \mathrm{H}_{2} \mathrm{O}$ in nitrogen (balance). GHSV $\sim 150 \mathrm{~L} / \mathrm{g} * \mathrm{hr}$. Temperature ramp (heating) rate is $2{ }^{\circ} \mathrm{C} / \mathrm{min}$.

While we succeeded in preparing high surface area pure-phase theta-alumina and focused on this catalytic support as a representative example in the current study, our findings can be generalized in a broader context. As we noted after prolonged heating at $1,050^{\circ} \mathrm{C}$, rhombus-platelet gammaalumina $\left(\mathrm{SA} \sim 70 \mathrm{~m}^{2} / \mathrm{g}\right.$ ) transforms into the mixture of delta,theta-phases [after approximately 48 hours of heating at this temperature structural evolution is complete and stabilized delta-theta alumina mixed phase is produced with essentially the same surface area]: loading catalytically active phases on this stabilized phase is expected to provide benefits of high-temperature 
hydrothermal stability. Please note, however, that theta-alumina with major (100) facet has the lowest surface energy and so we chose it as the most extreme representative example but the method we describe based on pre-heating gamma-alumina/boehmite of certain morphologies to high temperature $\left(1,000-1,100{ }^{\circ} \mathrm{C}\right)$ and ensuring structural evolution of the resulting material is complete, is a general method to produce catalytically active materials with enhanced hydrothermal stability.

In summary, our insight into surface and structure of transition aluminas allowed us to produce industrially relevant metal-alumina composite catalysts with remarkable hydrothermal stability for various catalytic applications without the need to use toxic metals and rare-earths. This represents a breakthrough in the field of thermally robust catalytic materials and opens an opportunity to widely use these materials in catalytic, and environmental applications.
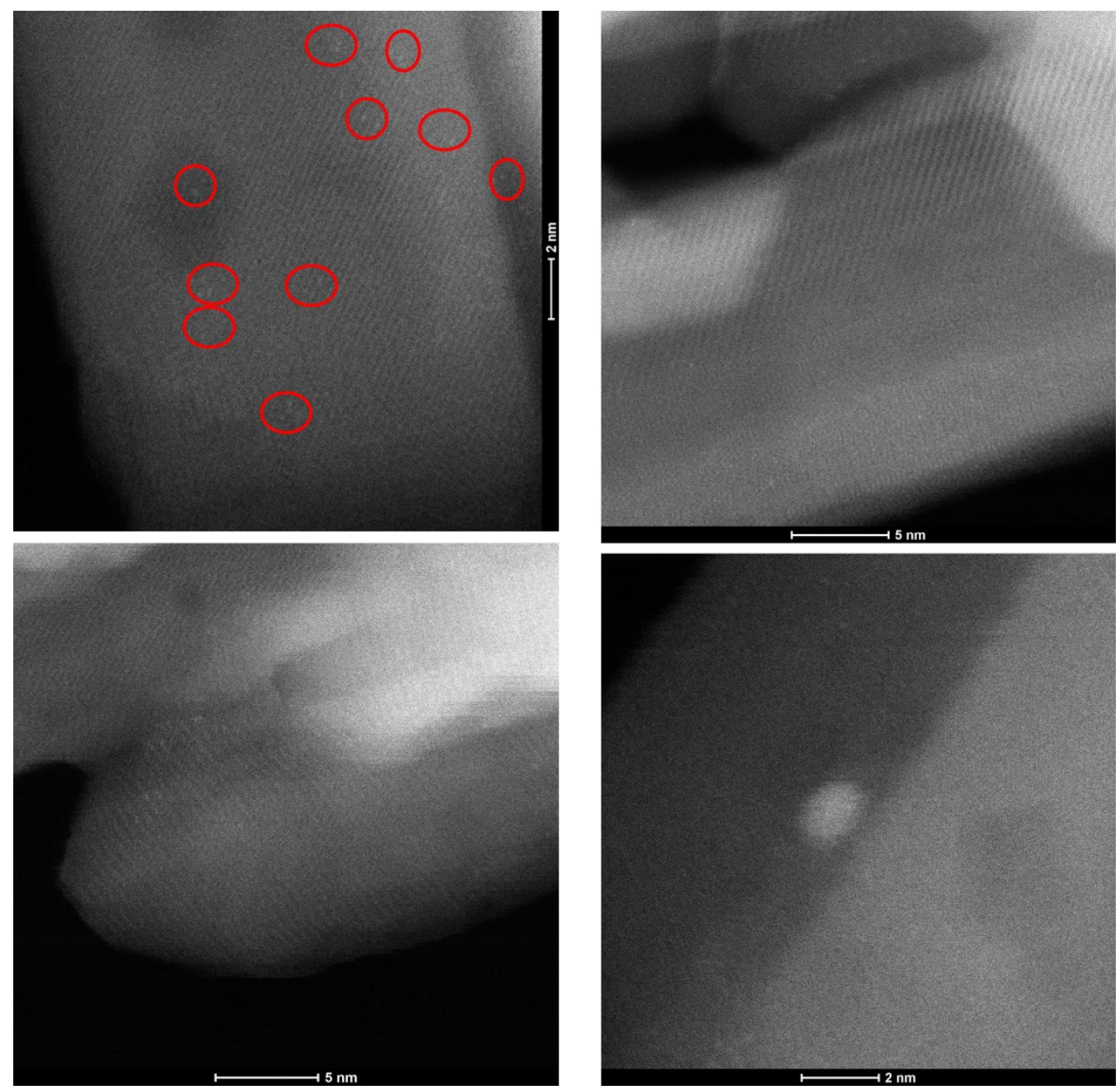

Fig. 6. HAADF-STEM image of $0.07 \mathrm{wt} \% \mathrm{Rh} /$ theta-alumina rods (hydrothermally aged at $1,000{ }^{\circ} \mathrm{C}$ and then tested for $\mathrm{NO}$ reduction). 


\section{References}

${ }^{1}$ Ipatiew, W. Zur Frage Über die Zersetzung des Äthylalkohols in Gegenwart verschiedener Katalysatoren. J. Prakt. Chem. 1903, 67, 420, DOI: 10.1002/prac.1903067013

2 Steward, M. W.; Clark, H. W.; Coffey, D. P.; Luo, L.; Schweizer, A. E. U.S. Patent 9242919, to Dow Global Technologies, 2016.

3 Zecchina, A.; Califano, S. The Development of Catalysis: A History of Key Processes and Personas in Catalytic Technology; John Wiley \& Sons, 2017.

${ }^{4}$ Grosse, A. V.; Ipatieff, V. N. Catalytic Dehydrogenation of Gaseous Paraffins. Ind. Eng. Chem. 1940, 32, 268272, DOI: $10.1021 / \mathrm{ie} 50362 \mathrm{a} 024$

${ }^{5}$ Boudart, M. Catalysis by Supported Metals, Chapter XX, Advances in Catalysis, Vol. 20; Frankenberg, W. G. Ed.; Academic Press, 1969.

${ }^{6}$ Buchel, K. H.; Moretto, H.-H.; Woditsch, P. Industrial Inorganic Chemistry, 2nd ed.; Wiley-VCH: Weinheim, 2000.

${ }^{7}$ Sachtler W.M.H. (2002) Catalysis from Art to Science. In: Carley A.F., Davies P.R., Hutchings G.J., Spencer M.S. (eds) Surface Chemistry and Catalysis. Fundamental and Applied Catalysis. Springer, Boston, MA

${ }^{8}$ K. Khivantsev, N. R Jaegers, J.-H. Kwak, J. Szanyi, L. Kovarik, Angew. Chem. Int. Ed. 2021, 60, 17522-17530

${ }^{9}$ L. Kovarik, M.E. Bowden, J. Szanyi, J. Catal. 2021, 393, 357-368.

${ }^{10}$ L. Kovarik, M. Bowden, A. Andersen, N. R. Jaegers, N. Washton, J. Szanyi, Angew. Chem. Int. Ed. 2021, 132, 21903-21911.

11 Twigg, MV . Catalytic control of emissions from cars. Catal Today 2011; 163: 33-41.

${ }^{12}$ Heck RM, Farauto RJ (2002) Catalytic air pollution control: commercial technology, 2nd edn. Wiley, New York

${ }^{13}$ H Jeong, O Kwon, BS Kim, J Bae, S Shin, HE Kim, J Kim, H Lee, Nature Catalysis 3 (4), 368-375 (2020)

${ }^{14}$ Kovarik, L.; Bowden, M.; Genc, A.; Szanyi, J.; Peden, C. H. F.; Kwak, J. H. J. Phys. Chem. C 2014, 118, 18051-18058.

${ }^{15}$ Kovarik, L.; Bowden, M.; Shi, D.; Washton, N. M.; Andersen, A.; Hu, J. Z.; Lee, J.; Szanyi, J.; Kwak, J. H.; Peden, C. H. F. Chem. Mater. 2015, 27, 7042-7049.

${ }_{16}$ Kovarik, L.; Genc, A.; Wang, C.; Qiu, A.; Peden, C. H.; Szanyi, J.; Kwak, J. H. J. Phys. Chem. C 2013, 117, 179-186.

${ }^{17}$ L. Kovarik, M. Bowden, D. Shi, J. Szanyi, C. H. F. Peden. J. Phys. Chem. C 2019, 123 9454-9460.

18 J. Lee, H. Jeon, D.G. Oh, J. Szanyi, J.H. Kwak, Appl. Catal., A 500 (2015) 58-68.

${ }^{19}$ R. Prins, J. Catal. 2020, https://doi.org/10.1016/j.jcat.2020.10.010

${ }^{20}$ G. Busca, Catal. Tod. 2014, 226, 2-13.

${ }^{21}$ Z. Lodziana, N.-Y. Topsøe, J.K. Nørskov, A negative surface energy for alumina, Nat. Mater. 3 (2004) $289-293$.

${ }^{22}$ Weaver, J. F.; Hinojosa, J. A., Jr.; Hakanoglu, C.; Antony, A.; Hawkins, J. M.; Asthagiri, A. Catal. Today 2011, 160,213

${ }^{23}$ K. Khivantsev, C. Vargas, J. Tian, L. Kovarik, N. R. Jaegers, J. Szanyi, Y. Wang, Angew. Chem. Int. Ed. 2021, $133,395-402$

\section{Acknowledgments:}

The research described in paper is part of the Quickstarter Initiative at Pacific Northwest National Laboratory. It was conducted under the Laboratory Directed Research and Development Program at PNNL, a multiprogram national laboratory operated by Battelle for the U.S. Department of Energy (DOE) under Contract DE-AC05-76RL01830. The research described in this paper was performed in the Environmental Molecular Sciences Laboratory (EMSL), a national scientific user facility sponsored by the DOE's Office of Biological and Environmental Research. This work was 
supported by US Department of Energy, Office of Science, Office of Basic Energy Sciences, Division of Chemical Sciences, Biosciences, and Geosciences.

Competing interests: Authors filed for a patent in November 2020.

Data and materials availability: All data is available in the main text or the supplementary materials. 


\title{
Supplementary Information
}

\section{Phase and facet-engineering of transition alumina leads to (hydro)thermally robust alumina-supported metal catalysts in the absence of toxic and rare- earth additives}

\author{
Authors: Konstantin Khivantsev ${ }^{1 *} \dagger$, Ja-Hun Kwak ${ }^{2 *} \uparrow$, Nicholas R. Jaegers ${ }^{1}$, Yong Wang, ${ }^{1,3 *}$ \\ Janos Szanyi ${ }^{1 *}$, Libor Kovarik ${ }^{1^{*} \dagger}$
}

\author{
Affiliations: \\ ${ }^{1}$ Institute for Integrated Catalysis, Pacific Northwest National Laboratory, Richland, WA 99352 , \\ USA. \\ ${ }^{2}$ Ulsan National Institute of Science and Technology (UNIST), South Korea \\ ${ }^{3}$ The Gene \& Linda Voiland School of Chemical Engineering and Bioengineering, Washington \\ State University, Pullman, WA, USA \\ * Correspondence to: LK, JHK, JSz, KK \\ $\uparrow$ denotes equal contribution
}

\section{Materials and methods:}

Rhombus-platelet $\gamma$-alumina used was synthesized from aluminum isopropoxide via a hydrolysis method. More specifically, approximately $10 \mathrm{~g}$ of aluminum isopropoxide was added to $\sim 50 \mathrm{~mL}$ of water with vigorous stirring at $80{ }^{\circ} \mathrm{C}$ for $1 \mathrm{~h}$. The mixture was transferred to the $125 \mathrm{~mL}$ Teflon liner of a Parr reactor and placed into an oven and kept at $200{ }^{\circ} \mathrm{C}$ for $24 \mathrm{~h}$. After cooling to room temperature, the powder was collected by filtration, washed with distilled water, and dried at $100{ }^{\circ} \mathrm{C}$. The as-synthesized boehmite powder was then calcined at $800{ }^{\circ} \mathrm{C}$ for $2 \mathrm{~h}$ to convert it to rhombus-platelet $\gamma$-alumina with surface area of approximately $75 \mathrm{~m}^{2} / \mathrm{g}$.

Commercial SBA-200 $\gamma$-alumina from SASOL with surface area $\sim 200 \mathrm{~m}^{2} / \mathrm{g}$ was used without additional pretreatment. Commercial SBA-90 $\gamma$-alumina from SASOL with surface area $90 \mathrm{~m}^{2} / \mathrm{g}$ was used without additional pre-treatments.

Rod-like $\gamma$-alumina (with surface area $\sim 75 \mathrm{~m}^{2} / \mathrm{g}$ ) was synthesized according to the previous method at $\mathrm{pH} \sim 4[8,18]$. 
Various samples were heat treated in a tube furnace at $1,000-1,100{ }^{\circ} \mathrm{C}$ for a period of $0.5-48$ hours.

Rod-like $\gamma$-alumina was transformed into pure theta-alumina rods by heat-treating at $1,050{ }^{\circ} \mathrm{C}$ for 4 hours. Note that further heating this sample at $1,050^{\circ} \mathrm{C}$ for longer time or at $1,100{ }^{\circ} \mathrm{C}$ does not lead to any change of the sample.

$\gamma-\mathrm{Al}_{2} \mathrm{O}_{3}$ (SBA-200) and theta-alumina (rod-like) were loaded with $3 \mathrm{wt} \%$ of Pd by wet impregnation (incipient wetness) using $\left[\mathrm{Pd}\left(\mathrm{NH}_{3}\right)_{4}\right]\left(\mathrm{NO}_{3}\right)_{2}$ in water $(10 \%$ by weigh solution, Sigma). The sample was calcined in dry air flow at $600{ }^{\circ} \mathrm{C}$ for 5 hours to decompose nitrate.

$\gamma-\mathrm{Al}_{2} \mathrm{O}_{3}$ (SBA-200) and theta-alumina (rods) were loaded with $0.07 \mathrm{wt} \% \mathrm{Rh}$ using rhodium nitrate hydrate ( $36 \mathrm{wt} \% \mathrm{Rh}$, Sigma) via incipient wetness impregnation. The sample was then dried and calcined $700{ }^{\circ} \mathrm{C}$ for 5 hours to decompose nitrate.

Microscopy analysis was performed with a FEI Titan 80-300 microscope operated at $300 \mathrm{kV}$. The instrument is equipped with a CEOS GmbH double-hexapole aberration corrector for the probe-forming lens, which allows for imaging with $0.1 \mathrm{~nm}$ resolution in scanning transmission electron microscopy mode (STEM). HAADF-STEM images were acquired with a high angle annular dark field (HAADF) detector with inner collection angle set to $52 \mathrm{mrad}$.

${ }^{27} \mathrm{Al}$ MAS NMR measurements were performed at room temperature on a Bruker $850 \mathrm{MHz}$ NMR spectrometer, operating at a magnetic field of $19.975 \mathrm{~T}$. The corresponding ${ }^{27} \mathrm{Al}$ Larmor frequency is $221.4125 \mathrm{MHz}$. A single pulse sequence comprised of a $\pi / 9$ pulse width of $0.3 \mu \mathrm{s}$, a recycle delay of $2 \mathrm{~s}$, and an acquisition time of $30 \mathrm{~ms}$ was employed to collect the free induction decays (FID). To enhance the intensity of the observed spectral features over the noise, 4,096 repetitions were employed for each FID. Each collected FID was subsequently Fourier Transformed to the frequency domain where both zero and first order phase corrections were applied. The broad spectrometer background signal was collected with a sample containing no Al species under the same conditions and subsequently subtracted from each $\mathrm{Al}_{2} \mathrm{O}_{3}$ spectra. All NMR data were acquired at a sample spinning rate of $18.7 \mathrm{kHz}( \pm 5 \mathrm{~Hz})$ and externally referenced to 1.0 $\mathrm{M}$ aqueous $\mathrm{Al}\left(\mathrm{NO}_{3}\right)_{3}(0 \mathrm{ppm})$.

We employed the Vienna Ab- initio Simulation Package (VASP), which uses pseudopotentials and a plane wave basis set. All calculations reported in this work were done with projector augmented wave (PAW) potentials and the Generalized Gradient Approximation (GGA) of 
Perdew and Wang (PW91) for the exchange correlation potential. We used the Monkhorst-Pack scheme for k-point sampling of the Brillouin zone.

X-ray diffraction (XRD) patterns were collected on a Rigaku Mini Flex II bench top X-ray diffractometer using a $\mathrm{Cu}-\mathrm{K} \alpha$ radiation of $0.154056 \mathrm{~nm}(30 \mathrm{kV}$ and $15 \mathrm{~mA})$. Experiments were conducted on a powder sample holder in a $2 \theta$ range of $10-80^{\circ}$, with a step size of $0.02 \%$ s. All measurements were performed under ambient conditions.

Hydrothermal aging (HTA) was performed at specified temperature for 16 hours in a flow reactor with GHSV $\sim 150$ or $300 \mathrm{~L} / \mathrm{g} * \mathrm{hr}$. The gas mix, used for HTA, containing air $\sim 10 \% \mathrm{H}_{2} \mathrm{O}$ in air.

All catalytic experiments were performed in the flow-through quartz reactor.

NO reduction catalytic experiments were conducted in a plug-flow reactor system with powder samples (120 mg, 60-80 mesh) loaded in a quartz tube, using a synthetic gas mixture containing $460 \mathrm{ppm}$ of $\mathrm{NO}, 1,750 \mathrm{ppm} \mathrm{CO}$ and $\sim 3 \% \mathrm{H}_{2} \mathrm{O}$ balanced with $\mathrm{N}_{2}$ at a flow rate of 300 sccm (corresponding to GHSV $150 \mathrm{~L} / \mathrm{g} * \mathrm{hr}$ ). All the gas lines were heated to over $100{ }^{\circ} \mathrm{C}$. Concentrations of reactants and products were measured by an online MKS MultiGas 2030 FTIR gas analyzer with a gas cell maintained at $191{ }^{\circ} \mathrm{C}$. Two four-way valves were used for gas switching between the reactor and the bypass. Heating rate was $2{ }^{\circ} \mathrm{C} / \mathrm{min}$.

Standard methane oxidation tests were conducted in a plug-flow reactor system with powder samples (60 mg mg, 60-80 mesh) loaded in a quartz tube, using a synthetic gas mixture that contained $\sim 850$ ppm of methane, $10 \%$ oxygen, $\mathrm{H}_{2} \mathrm{O}(\sim 3 \%)$ balanced with $\mathrm{N}_{2}$ at a flow rate of 300 $\mathrm{sccm}$. All the gas lines were heated to over $100{ }^{\circ} \mathrm{C}$. Concentrations of reactants and products were measured by an online MKS MultiGas 2030 FTIR gas analyzer with a gas cell maintained at $191{ }^{\circ} \mathrm{C}$. GHSV for all methane oxidation experiments was $300 \mathrm{~L} / \mathrm{g} * \mathrm{hr}$. Heating or cooling rate was $2{ }^{\circ} \mathrm{C} / \mathrm{min}$. 


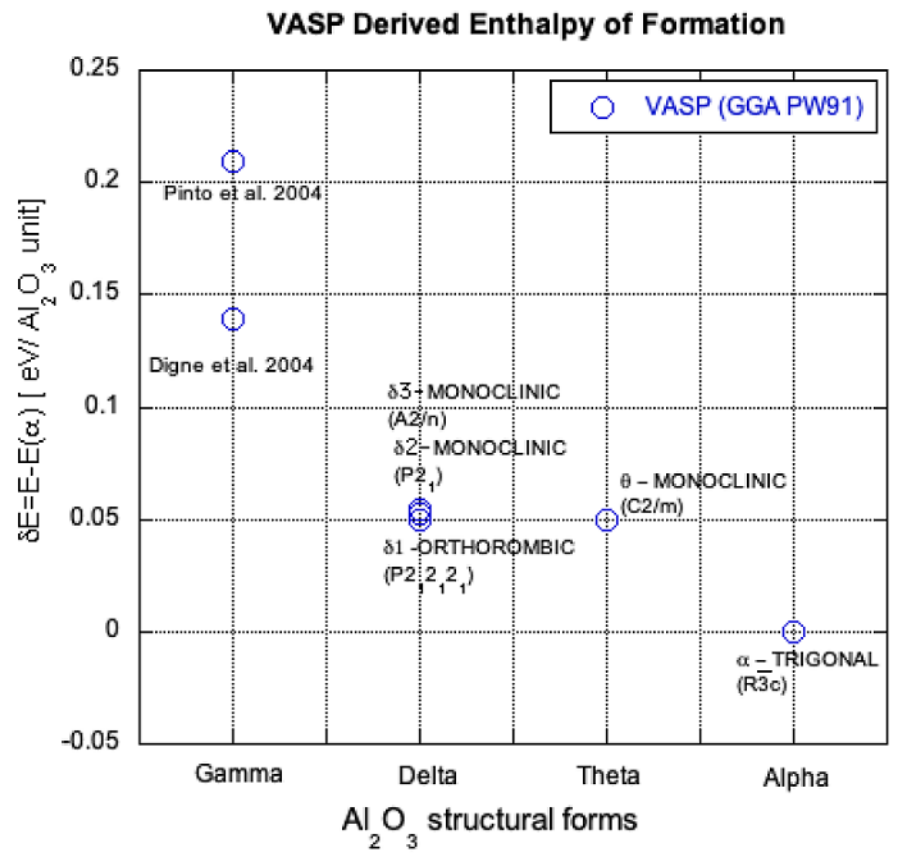

Fig. S1. Relative stabilities (enthalpies of formation) estimated for different transition aluminas. Since the real structure of gamma-alumina is unknown, only estimates are available based on approximations from the literature. It is obvious that delta- and theta-phases have similar enthalpies of formations. That is one of the reasons why they usually evolve simultaneously upon thermal treatment of gamma-alumina.

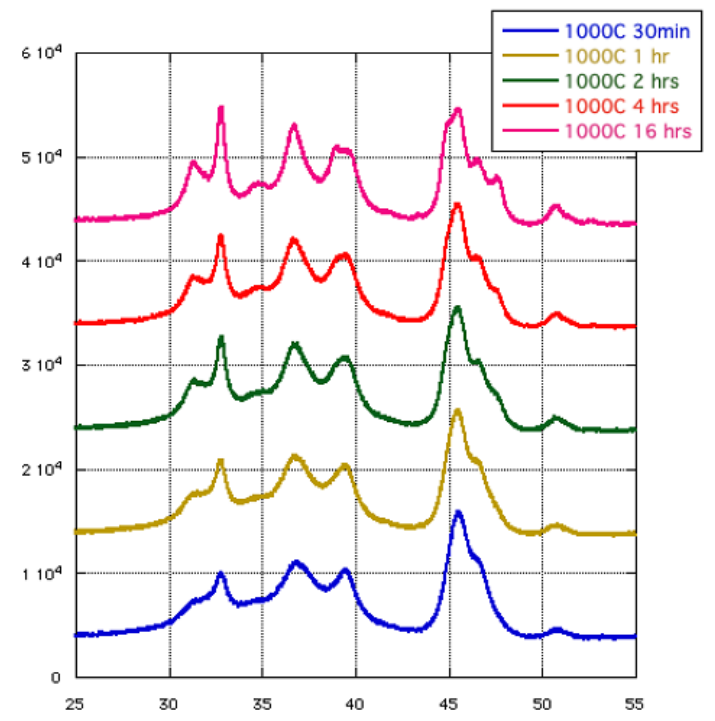

Fig. S2. XRD patterns of SBA-200 treated at $1,000^{\circ} \mathrm{C}$ for different time durations. 


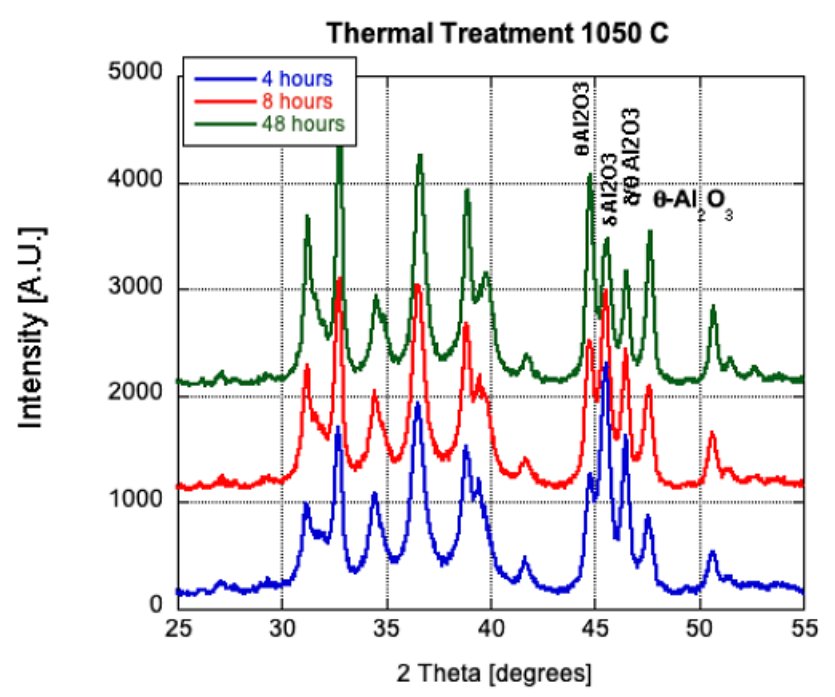

Fig. S3. XRD patterns of rhombus-platelet gamma-alumina treated at $1,050^{\circ} \mathrm{C}$ for different time durations.

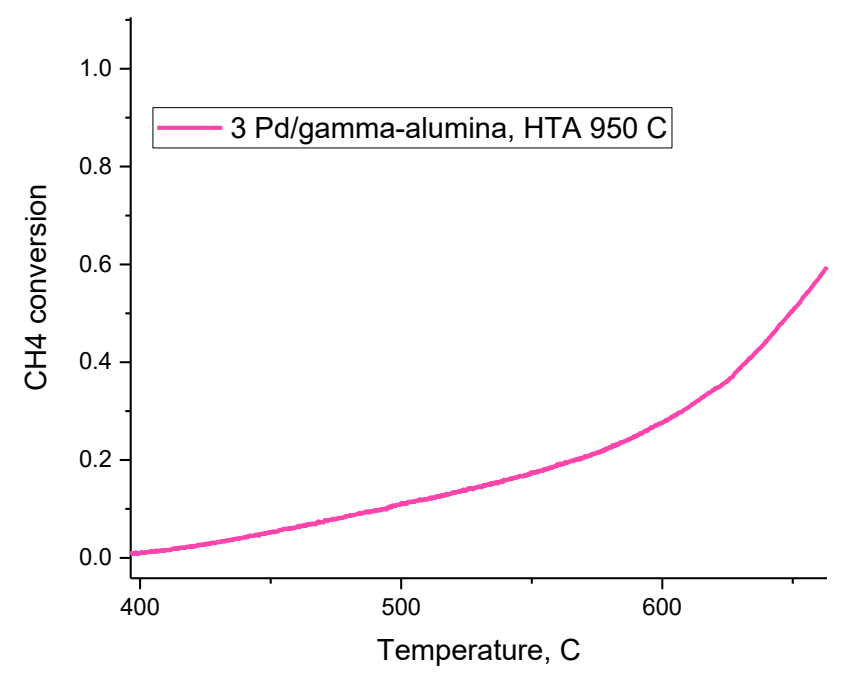

Fig. S4. Methane combustion performance of $3 \mathrm{wt} \% \mathrm{Pd} / \mathrm{SBA}-200$ sample after hydrothermal aging at $950{ }^{\circ} \mathrm{C} . \sim 3 \%$ $\mathrm{H}_{2} \mathrm{O}, \mathrm{CH}_{4} \sim 850 \mathrm{ppm}, \mathrm{O}_{2} \sim 10 \%$, balance nitrogen. GHSV $\sim 300 \mathrm{~L} / \mathrm{g} * \mathrm{hr}$. Temperature up ramp $2^{\circ} \mathrm{C} / \mathrm{min}$ 


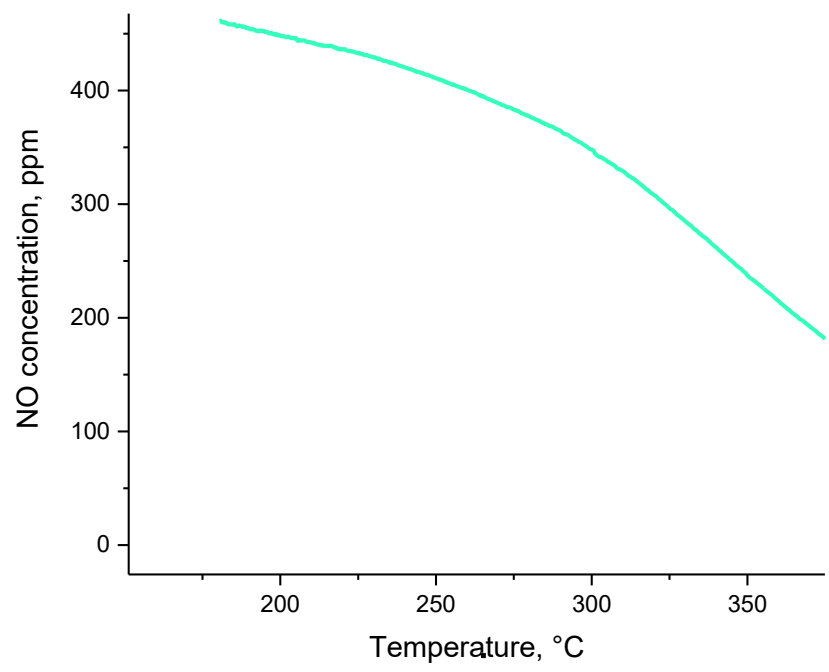

Fig. S5. NO reduction performance of $0.07 \mathrm{wt} \% \mathrm{Rh} / \mathrm{SBA}-200$ catalyst that was hydrothermally aged at $1,000{ }^{\circ} \mathrm{C} .120$ $\mathrm{mg}$ catalyst. $450 \mathrm{ppm} \mathrm{NO}, 1,750 \mathrm{ppm} \mathrm{CO}, \sim 3 \% \mathrm{H}_{2} \mathrm{O}$ in nitrogen (balance). GHSV $150 \mathrm{~L} / \mathrm{g} * \mathrm{hr}$. Heating rate was $2^{\circ} \mathrm{C} / \mathrm{min}$. 